Copyright (C) 2021 by Cherkas Global University

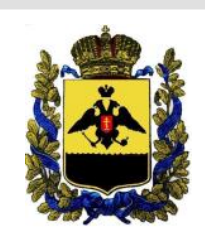

Published in the USA

Bylye Gody

Has been issued since 2006.

E-ISSN: $2310-0028$

2021. 16(4): 1877-1885

DOI: $10.13187 /$ bg.2021.4.1877

Journal homepage:

https://bg.cherkasgu.press

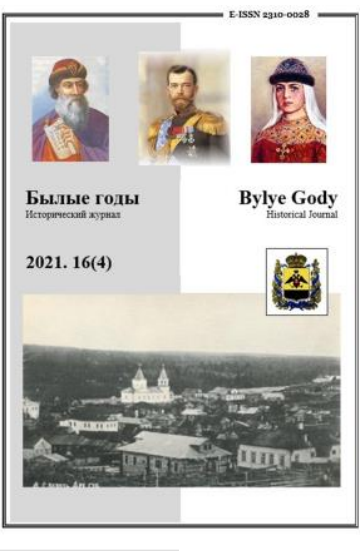

\title{
Folk Readings as one of the Forms of Organization of Rural Extracurricular Education in the Orel Province in the second half of the XIX - early XX centuries
}

\author{
Oksana V. Klevtsova a, ${ }^{\text {* }}$, Nikolay A. Zhirov a \\ a Bunin Yelets State University, Russian Federation
}

\begin{abstract}
The article is devoted to the analysis of the situation in the field of literacy among the rural, mainly peasant population through holding public readings. The authors made an attempt to study the legislative framework, to study the state policy and recommendations on the methodology for organizing mass public readings. The relevance of the study lies in the poor knowledge of the out-of-school form of education in the Russian Empire, including within the framework of the Oryol province, in the period under study.

Particular attention was paid to holding readings on the territory of the Oryol province, analyzing the demand for this area of work among the peasant population.

In the course of the research, the following methods were used: general scientific methods of analysis and synthesis, the principle of historicism, comparative historical, mathematical and other methods.

As a result of the study, the reasons for the popularity of folk readings among the villagers were established. At the same time, there is a noticeable lack of consistency in the conduct of this work, a plan for the organization and dissemination of religious and moral education of young people has not been formed. The reasons that hinder this process are identified: a lack of funds, a meager material and technical base of libraries, a lack of qualified teachers. The state has shifted the responsibility to the local authorities and the public. At the same time, throughout the entire period under study, there has been a steady increase in interest among the peasant population in folk readings and books.
\end{abstract}

Keywords: religious and moral readings, national library, extracurricular education, peasantry, zemstvo, the Orel province.

\section{1. Введение}

Система начального образования Российской империи к середине XIX в. была представлена двумя основными типами школ - государственными земскими и учебными заведениями духовного ведомства. Частные школы, особенно в сельской местности, были редким явлением. Все перечисленные школы давали минимум знаний, а ученики в большинстве случаев после завершения обучения оставались полуграмотными, с трудом могли читать и писать. Но это не означало, что крестьянство не тянулось к знаниям, наоборот, потребность в грамотных людях росла, и осознание необходимости получения образования стало повсеместным явлением.

Специфика крестьянской сельской жизни, где ребенок достаточно рано вовлекался в аграрный цикл работ и к подростковому возрасту становился полноценным работником в своей семье, не предполагала иного пути получения знаний, кроме обучения в начальной школе. Потребность в чтении, как правило, возникала в более осознанном возрасте, но школ или иных учебных курсов для взрослого крестьянства не существовало. Для возмещения пробела в образовании взрослых жителей села и их детей был выбран путь распространения грамотности через систему внешкольного массового образования, а основной формой внедрения и популяризации знаний стали народные чтения.

${ }^{*}$ Corresponding author

E-mail addresses: ksenijmel@yandex.ru (O.V. Klevtsova), zhirov-nikolai@mail.ru (N.A. Zhirov) 
В настоящее время возникла потребность воссоздания целостного представления о наследии отечественной педагогики, ее успехах в разные исторические периоды, в том числе и дореволюционную эпоху. Изучение истории внешкольных форм обучения, в том числе посредством организаций народных чтений, распространения библиотечной сети, позволяет раскрыть процесс распространения грамотности среди населения нашей страны. В этой связи особый интерес заслуживает региональная история становления провинциальной библиотечной системы и распространения грамотности в сельской местности. Изучение роли религиозно-нравственных чтений в крестьянской среде на примере отдельно взятого региона позволит детализировать процесс и выявить специфику региона в решении данного вопроса.

\section{2. Материалы и методы}

В качестве источников авторами были использованы архивные документы и опубликованные материалы по предложенной теме. В первую очередь это различные статистические сборники по системе школьного образования региона, а также периодическая печать, а именно газета «Орловские епархиальные ведомости». В этой газете помещались заметки учащих священно- и церковнослужащих о школах духовного ведомства, о методиках преподавания, о составе учебной литературы и т.д. В рамках изучаемой темы особенно ценными являются очерки с описанием организованных нравственно-религиозных чтений для крестьян (какая литература освещалась, популярность этих чтений, с какими проблемами сталкивались местные священники при проведении мероприятий). Основная методика исследования заключается в комплексном изучении документальных материалов, хранящихся в Государственном архиве Орловской области, а также в детальном анализе научной литературы, посвященной исследуемой тематике.

В Государственном архиве Орловской области (г. Орел, Россия) в фондах канцелярии губернатора Орловской губернии (Ф. 580) и губернской земской управы (Ф. 525) имеется ряд документов, содержащих информацию о внедрении и развитии внешкольного образования в исследуемом регионе. В этой связи напрашивается мысль, что внешкольные формы просветительской деятельности были под бдительным контролем губернатора и земства и имели важнейшее значение в распространении грамотности среди широких масс населения.

Нами были использованы следующие методы:

- сравнительно-исторический, который позволил проследить становление и развитие народных библиотек в конце XIX - начале XX вв. на территории Российской империи, и в частности в Орловской губернии, и дал возможность выявить как закономерности в процессе организации народных чтений, так и различия;

- математический - статистические данные позволили раскрыть динамику процесса внедрения народных чтений как одной из важных форм внешкольного образования;

- метод историзма предоставил возможность рассмотреть явления в их историческом развитии в связи с социальными, политическими и общекультурными процессами и выявить предпосылки становления народных чтений на территории Орловской губернии, а также детально изучить этапы организации чтений.

\section{3. Обсуждение}

В современной отечественной исторической науке тема дореволюционного школьного образования представлена достаточным количеством научных исследований, значительная часть которых освещает региональные особенности этого вопроса на уровне губерний и отдельных уездов (Белослудцева, 2009; Ивако, 2002). В этих работах в основном изучалось функционирование гражданских школ и учебных заведений духовного ведомства, проводился анализ материальнотехнического состояния школ, педагогических кадров, финансирования и т.д.

Исследования зарубежных историков по представленной тематике немногочисленны и в основном освещают не столько систему сельского образования или внешкольного обучения в империи, сколько степень ее воздействия на жизнь крестьян (Eklof, 1990).

К работам общероссийского характера стоит отнести публикации А.В. Буганова и других историков (Буганов, 2008; Зайцева, 2010; Маркарьян, 2013), в которых была затронута тема внешкольного образования в Российской империи, но касалось это в основном городских слоев населения.

По истории дореволюционного образования Орловской губернии в настоящее время существует немало научных работ, представленных крупными диссертационными исследованиями, а также отдельными статьями в научных журналах (Барынкина, Барынкин, 2015; Хабалева, 2015). Отдельно отметим вклад в изучение системы сельского образования в Орловской губернии авторов данной статьи, посвятивших этой теме более 15 научных публикаций, в том числе и монографии в рамках исполнения грантов (Жиров, 2020: 99-108; Клевцова, Жиров, 2019; Клевцова, Жиров, 2020).

В то же время вопрос изучения внешкольного сельского образования, особенно на региональном уровне, в том числе в рамках Орловской губернии, все еще мало исследован. В последние годы стали появляться отдельные публикации (Козлов, 2012; Першина, 2016), но их количество явно недостаточно, что обуславливает актуальность исследований по этой тематике. 


\section{4. Результаты}

Либеральные реформы второй половины XIX в. способствовали возникновению необходимости распространения основ грамотности среди сельских жителей, в первую очередь получивших свободу бывших владельческих крестьян. Организовать массовое внедрение школьного образования было невозможно по целому ряду причин: отсутствию финансов, недостаточному количеству учителей, непониманию крестьянством смысла получения самого образования и т.д. Перераспределение обязанностей по распространению основ грамотности среди освобожденного крестьянского населения между государством, церковью и местными органами самоуправления не могло принести скорейших положительных результатов. Особую проблему вызывал постоянный дефицит квалифицированных педагогических кадров (Филоненко, 2004: 137-142). Учителей начальных земских школ к 1914 г. было вполне достаточно, но большая часть преподавателей в школах духовного ведомства, особенно в школах грамотности, была представлена местным клиром (дьяки, причетники). Большая часть из них имела либо домашнее, либо неоконченное семинарское образование, была поверхностно знакома с педагогическими методами.

Вследствие этого для решения проблемы безграмотности населения доступными средствами и для последующей мотивации в получении образования подрастающими поколениями сельских обывателей в 1871 г. в Петербурге было издано Первое Высочайшее повеление об устройстве народных чтений. Религиозно-нравственные чтения должны были стать одной из форм организации внешкольного обучения крестьянской молодежи и взрослого малограмотного населения дореволюционной России.

Инициатива распространения народных чтений принадлежала санкт-петербургскому градоначальнику генерал-адъютанту Ф.Ф. Трепову, который считал, что «только постепенным путем смягчения в народе грубых нравов, возвышением в нем нравственного и умственного уровня он может быть отвлечен от пагубной страсти к вину» (Вахтеров, 1897: 43-44).

8 декабря 1871 г. была организована комиссия для обсуждения доклада генерала-адъютанта Трепова. Она определила, что народные чтения должны стать занимательными и полезными для народа, понятными простому человеку, должны содержать наглядные пособия и интересные опыты. Каждое чтение должно представлять собой законченное занятие, рассчитанное на то, что посетитель мог здесь присутствовать случайно и мог не прийти на следующий сеанс.

Комиссия приняла решение о том, что контролировать работу чтений станет Министерство народного просвещения. В 1876 г. в свет вышли правила устройства чтений в губернских и уездных городах, а также сельской местности. В соответствие с документом чтения можно было устраивать с разрешения попечителей учебных округов и с согласия местного губернатора. Книжные пособия для чтений рекомендовались ученым комитетом Министерства народного просвещения, а духовную литературу определял Священный синод (Вахтерова, 1897: 5-46).

В 1876 г. были опубликованы «Правила о бесплатных народных читальнях и о порядке надзора за ними». В соответствие с этими правилами библиотеки составляли список допустимой для чтения литературы, одобренной Министерством народного просвещения (Сборник справок..., 1899: 163).

Надзор за народными чтениями осуществляли уездные предводители дворянства и земские начальники, председатели земских уездных управ, уездные исправники (Першина, 2016: 192). Они должны были следить за тем, чтобы в читальни не попадали нерекомендованные книги, а сами библиотеки не служили местом собраний и совещаний.

В городах чтения организовывались под надзором директоров народных училищ или инспектора губернии. Местами устройства чтений могли быть дома, где располагались училища, школы или помещения в казенных и общественных зданиях. При этом не допускалось организовывать чтения на фабриках. Публичные чтения для рабочих устраивались с разрешения губернатора (Сборник справок..., 1899: 166).

Для неграмотного население единственным способом получения информации были чтения произведений вслух. Для организации чтений было необходимо получить разрешение. Его давали благонадежным гражданам. Место проведения чтений располагалось вдали от продажи спиртного. Время сеанса должно было быть удобным для посещения большей части населения (Сборник справок..., 1899: 29).

В 1891 г. последовало распоряжение Министерства народного просвещения об устройстве народных чтений в помещениях училищ в дни, свободные от процесса преподавания (Сборник справок..., 1899: 28).

В Орловской губернии организаторам религиозно-нравственных чтений было рекомендовано начинать беседы на темы, близкие народу. Необходимо было подбирать для изучения повествования, имеющие религиозный характер, «которые удовлетворяли любознательность» народа. Потом можно было приступать к изучению литературы исторического и беллетристического содержания. Такая форма организации чтений позволяла разнообразить обучение и сохранить интерес к занятиям среди большего числа слушателей. Рекомендовалось концентрировать внимание на изучении важных событий Российской истории, подчеркивая заслуги перед Отечеством отдельных исторических личностей (ОЕВ, 1899: 554). 
Перед религиозно-нравственными чтениями были поставлены важные задачи: при подборе материала необходимо ориентироваться не на то, чтобы сообщать прикладные знания, а рассказывать слушателям «материал воспитательный». Чтения должны дать «пищу для умственносердечной жизни» (Вахтеров, 1897: 31).

Чтения организовывались в рекомендованных помещениях при помощи так называемого волшебного фонаря. Этот прибор проецировал на белую стену или кусок материи изображение текста или рисунка в увеличенном размере. Сам фонарь можно было сделать из подручных средств, кроме самого проектора или увеличительного стекла (Котомина, 2016: 16-17).

Необходимо было проверить качество картинки, поэтому до начала чтений включали фонарь и фокусировали изображение, делая его более четким и ярким. За работой устройства следил техник, распорядитель чтений рассаживал слушателей, а чтец располагался возле фонаря и читал заранее подготовленный отрывок или произведение (Сборник справок..., 1899: 28-29).

На сельских чтениях все технические и организационные моменты ложились на плечи священника или учителя, ответственного за проведение чтений (Сборник справок..., 1899: 28-29). Такие мероприятия имели еще одну цель - заставить читателей полюбить произведения отечественных классиков. Особо востребованной в крестьянской среде была духовно-нравственная литература. Она составляла 60 \% от общего числа книг, хранящихся в сельских библиотеках. Постепенно популярность набирала светская историческая и художественная литература. Крестьяне любили читать и слушать произведения А.С. Пушкина («Капитанскую дочку», «Дубровского», «Историю пугачевского бунта», «Полтаву»), Л.Н. Толстого, Н.В. Гоголя, басни И.А. Крылова, стихи В.А. Жуковского, А. Кольцова, Н. Некрасова (Буганов, 2008: 56).

Земства и общества грамотности и трезвости устраивали книжные склады или библиотеки, а с помощью чтений усиливали интерес к отдельной книге. В письмах, направленных от волостных и губернских правлений, сообщалось, что в сельской местности с низким уровнем потребности в образовании взрослого населения народные чтения смогут разбудить интерес к «знанию и доверие к книгам» (Вахтерова, 1897: 31).

Низкая платежеспособность населения затрудняла самостоятельное приобретение книг крестьянством. Единственный способ повышения грамотности после окончания школы состоял в массовых общественных чтениях книг из казенного или земского фонда, о чем красноречиво свидетельствует переписка уездных земств с канцелярией губернатора, а также руководства дирекций народных училищ Орловской губернии с губернскими и уездными органами власти, отраженная в делопроизводственной документации (ГАОО. Ф. 525. Оп. 1. Д. 180).

Одним из важных инициаторов проведения массовых чтений в рамках внешкольного образования являлась Орловская духовная семинария. Она возникла в 1778 г. при епископе Амфросии Подобедове. Епископ Амфросий был ревностным поборником духовного просвещения, прославился заботой об образовании духовенства во всех епархиях, где ему приходилось служить. Первым ректором семинарии стал игумен Досифей (ОЕВ, 1899: 705-706).

Орловская семинария с 1896 г. взяла на себя обязанности еженедельно устраивать воскресные чтения. Инициатором данного направления просвещения стал ректор семинарии протоиерей Владимир Антонович Сахаров. Он взял на себя заботу по подбору литературы для чтений и составлял списки лекторов из числа воспитанников семинарии. Протоиерей Владимир лично присутствовал на занятиях и контролировал проведение чтений, а также посещаемость простого населения.

Большой интерес вызывали произведения отечественных писателей. В 1898 г. на народных чтениях в Орловской духовной семинарии читали отрывки из поэмы «Полтава» А.С. Пушкина, стихотворения Алексея Толстого и других (ОЕВ, 1899: 554).

С целью повышения интереса к занятиям чтения составлялись из двух частей - религиозного содержания и историко-литературного. Каждая часть длилась не более часа. Были проведены исследования и доказано, что простой народ не может внимательно слушать более 6о минут (ОЕВ, 1899: 554).

Сеансы чтений были востребованными. Каждый раз их посещало около 200-40о человек. Интерес не останавливали «даже дурная и грязная погода». Чтения при семинарии являлись для жителей «подходящим средством провести вечер праздничного дня с интересом и пользой» (ОЕВ, 1899: 554).

Посещение сеансов народных чтений удовлетворяло потребности в духовном, нравственном развитии людей разных возрастов и полов. Они отвлекали народ от праздного шатания по вечерним улицам, от похода в питейные заведения. Таким образом, чтения выполняли поставленную перед ними задачу - «дать разумно-нравственное развлечение простому народу, отвлечь его от погружения в тину низкопробных и часто безнравственных занятий и увеселений». Чтения помогали в антиалкогольной борьбе (OEB, 1899: 555).

В выборе источников пользовались рекомендациями Министерства народного просвещения. Особое внимание уделяли рекомендациям Харьковской комиссии по устройству народных чтений. От Харьковского общества по народным чтениям бесплатно или по приемлемым ценам получали картинки для волшебных фонарей. Предлагалось подобрать такой материал, который бы 
«дисциплинировал ум... и сообщал прикладные знания из областей, например арифметики» (Сборник справок..., 1899: 104).

Народные чтения устраивались в воскресные дни в земских и церковно-приходских школах. Общее число земских школ, где проводились такого рода занятия в 1896 г., составило 37, или 8,6 \% от всех школ данного типа. Сеансы проводились и в церковно-приходских школах губернии (в 12, или 13,7 \%). В среднем на чтениях присутствовало от 111 до 114 человек (Сборник справок..., 1899: 104).

Организаторы чтений пытались решить проблемы скученности слушателей. Так, в 1893 г. в городе Орле провели эксперимент. С 18 апреля было принято решение проводить чтения два раза в день. На первый утренний сеанс пускали детей. Именно они часто создавали неудобства при проведение вечерних чтений своими разговорами и хождениями по аудитории. Утром на чтения в этот день пришло 66 человек, а вечером - 83. Но случались дни, когда посещаемость утренних сеансов была низкой (Вахтеров, 1897: 202).

В городах чтения обычно устраивали в Народных домах, представлявших собой культурнопросветительные государственные учреждения (например, земские и муниципальные дома попечительства о народной трезвости), однако часто были и негосударственные Народные дома, построенные и финансируемые частными благотворителями. В сельской местности чтения проходили в волостных конторах, в школах, а также при церковных сторожках (Першина, 2016: 197).

Основными трудностями, с которыми приходилось сталкиваться при организации народных чтений, являлись теснота помещений, отсутствие книг и картин для волшебного фонаря. Некоторые организаторы народных чтений шли на различные эксперименты. Например, учитель В.Д. Рыжиков из села Подмаслова Мценского уезда сообщал, что изготовил волшебный фонарь в домашних условиях, но проблема возникла с поиском картинок: их просто невозможно было приобрести. В продаже имелись стекла с изображением карикатур. Учитель пытался самостоятельно расписать стекла картинками, но они не давали качественного изображения (Вахтеров, 1897: 117). Стоимость хорошего волшебного фонаря варьировалась от 30 до 50 руб. в зависимости от аудитории, на которую рассчитана демонстрация картинок и производителя. Самый дорогой волшебный фонарь был куплен воронежским земством в Лондоне за 550 руб., и 100 руб. стоила доставка. Этот фонарь поразил всех отчетливостью и яркостью изображений. Для закупки 500 демонстрационных картинок было выделено 300 руб. (Вахтеров, 1897: 121-122), что было значительной суммой, и позволить ее могло не каждое земство.

Из имеющихся данных за 1898 г. видно, что в губернии существовало 189 школьных библиотек при земских школах и 47 - при церковно-приходских. При этом 56 \% земских и 46 \% церковноприходских школ вообще не имели библиотечного фонда, а, следовательно, не проводили народных чтений (Сборник справок..., 1899: 105). Только министерские школы в Орловской губернии были оснащены библиотеками.

В этой связи стоит немного уделить внимания развитию библиотечного дела в губернии во второй половине XIX в. Открытие сельских библиотек-читален началось в 1890-х гг. и во многом было связано с проблемой дефицита книжного фонда в образовательных учреждениях (порой на целый класс имелось в наличии всего несколько учебников, а с художественной литературой дела обстояли еще хуже). Взрослые крестьяне даже если и имели тягу к чтению, но не могли этого сделать, так как в личном пользовании книги были редкостью, предметом роскоши. Именно поэтому открытие общественных библиотек стало важным шагом в развитии внешкольного образования (Стояновская, Стояновская, 2016: 38-48).

Основными источниками пополнения книжного фонда уже существующих библиотек являлись пожертвованные книги. Меценатами стали местные земские управы и частные лица. Епископ Александр Орловской и Севской епархии призывал помогать приходским библиотекам: «пусть богачблаготворитель щедро отпустит на нее средства». «Служить приходу - это дело не только одного пастыря, а каждого» (OEB, 1909: 722).

Так как сфера народного просвещения была в орбите наблюдения силовых структур Российской империи, то МВД было вынуждено курировать народные чтения. В рамках этой политики в 1876 г. в МВД были изданы «Правила о бесплатных народных читальнях и порядке надзора за ними», согласно которым местные органы власти не только следили за организацией работы библиотеки, но и могли назначать на должность библиотекаря ответственное лицо, определяли книжный фонд и т.д. Народная библиотека, как правило, открывалась при имеющемся учебном заведении, а местный учитель совмещал свою работу с обязанностями библиотекаря (Сборник справок..., 1899: 163).

Для книжного фонда существовали строгие цензурные правила, целью которых была охрана общественного порядка посредством нераспространения среди населения агитационной, «вредной для режима» литературы. Все печатные книжные пособия для чтений рекомендовались ученым комитетом Министерства народного просвещения. Духовную литературу рекомендовал Священный синод (Вахтеров, 1897: 45-46).

По этой причине массовое открытие народных библиотек-читален было очень затруднено. В качестве примера можно привести опыт открытия в 1902 г. типичной сельской библиотеки при земской школе в с. Навесном Ливенского уезда Орловской губернии. Сохранность архивных 
материалов по этому делу в подробностях описывает все сложности, с которыми пришлось столкнуться сельскому обществу местных крестьян, тяготевших к знаниям (ГАОО. Ф. 580. Ст. 2. Д. 2932. Л. 19).

Орловское земство ежегодно проводило мониторинг заинтересованности крестьян книгами и на основании этого писало отчеты «Что читает крестьянское население Орловской губернии и как оно относится к книге» (История..., 1897: 102). К началу ХХ в. сложилась определенная статистика, в которой, в частности, отмечалось: «Итак, мы располагаем сведениями относительно 11773 книг, зарегистрированных в 1296 дворах, что составит в среднем по губернии 9 книг на один двор, имеющий книги. К этой по губернской величине близко подходит среднее количество книг, приходящихся на один двор в уездах: Брянском, Ливенском, Малоархангельском, Мценском и Трубчевском; выделяются по количеству книг, приходящихся на двор, уезды: Елецкий, Орловский и Кромской; остальные уезды стоят ниже среднего» (Кузовлев и др., 2006: 50).

Большой популярностью пользовались домашние чтения. Здесь роль организатора брал на себя новый нарождавшийся тип просветителя - грамотный крестьянин. Он жил полной крестьянской жизнью, но являлся более грамотным, чем его односельчане. Он хотел делиться своими знаниями, именно поэтому устраивал в своей избе публичные чтения (Сборник справок..., 1899: 73).

Народные домашние чтения пользовались успехом и устраивались по воскресеньям в зимнее время, а в период сельскохозяйственных работ проводились в праздничные дни. Из-за тесноты помещений и устойчивого спроса эти мероприятия посещало мужское население деревни, женщины приходили, если оставались места (Сборник справок..., 1899: 73).

Общими усилиями на территории Орловской губернии с 1896 по 1900 гг. было проведено 235 сеансов в среднем по 47 чтений в год. В первое десятилетие XX в. число ежегодных постоянно проводимых чтений увеличилось более чем в два раза. К сожалению, события 1905-1907 гг., а также масштабные аграрные преобразования в Столыпинский период отвлекли как население, так и местную власть от дальнейшего расширения внешкольного образования в губернии, но стоит отметить, что число учебных заведений в сельской местности вплоть до начала Первой мировой войны ежегодно увеличивалось. При этих школах, а также при библиотеках-читальнях фактически в каждой волости на периодической основе, реже регулярно проводились бесплатные чтения для народа.

По сравнению с концом XIX в. произошло существенное увеличение школьных библиотек. В 1899 г. из 1507 сельских школ библиотеки имелись лишь в 1/3 учебных заведений (Обзор..., 1899: 76). К 1 января 1914 г. в Орловской губернии в уездах функционировало 1710 учебных заведений и более $70 \%$ из них были оснащены небольшими библиотеками с количеством экземпляров, не превышавшим 50 единиц. Таким образом, прослеживалась положительная динамика увеличения учебных заведений, имевших библиотеки, но ограниченный книжный фонд не позволял осуществлять широкую просветительскую деятельность среди крестьянства.

\section{5. Заключение}

Само понятие об уровне грамотности для исследуемого периода и выбранной категории населения является условным: грамотными считались как получившие образование в рамках начальной школы, так и без официального образования, но умевшие читать и писать. Начальное образование получали далеко не все дети, так как специфика аграрного производства, да и в целом ритм сельской жизни втягивали ребенка в хозяйственную занятость с раннего детства, а необходимость приобретения школьных знаний имела второстепенное значение. Несмотря на это, тяга к чтению среди сельских жителей региона к началу XX в. стала ощутимой. Именно поэтому стоит отметить важную роль внешкольного образования для крестьянства.

Религиозно-нравственные чтения стали одним из востребованных и приемлемых методов распространения грамотности среди сельских жителей. Методика организации чтений в воскресные дни позволяла охватить большую аудиторию. Соединение религиозного компонента и научных текстов позволяло не только нравственно воспитывать людей, но и обогащать их культурно и научно. Организация церковного и государственного контроля, с одной стороны, тормозила процесс, с другой - давала гарантии, что данные собрания не станут трибуной для антигосударственной пропаганды.

Орловская губерния стала одним из примеров в организации качественной работы чтений. Местные органы власти поддержали инициативу общественности, оказывали материальную помощь особо заинтересованным гражданам, поддерживали инициативу крестьян в организации чтений. Внедрение волшебных фонарей и музыкального сопровождения привлекали значительную часть молодежи, старшее поколение, воспитывали эстетически.

Народные чтения провели колоссальную работу в деле распространения грамотности среди населения, привлекли внимание общественности к проблеме школьного образования.

\section{Литература}

Барынкина, Барынкин, 2015 - Барынкина И.В., Барынкин В.П. Распространение начального образования и просвещения на селе в Центральной России в конце XIX - начале XX вв. 
(по материалам Калужской, Орловской и Смоленской губерний) // Вестник Брянского государственного университета. 2015. № 1. С. 22-24.

Белослудцева, 2009 - Белослудцева В.В. Церковно-приходская школа в системе начального образования в России во второй половине XIX в. // Вестник Пермского университета. 2009. Выпуск 4 (11). С. 95-96.

Буганов, 2008 - Буганов A.B. О грамотности и чтении русских крестьян XIX - начала XX веков // Преподаватель ХХІ века. 2008. № 2. С. 50-57.

Вахтерова, 1897 - Вахтерова В. Народные чтения. СПб.: «Русская школа», 1897. 209 с.

ГАОО - Государственный архив Орловской области (ГАОО).

Жиров, 2020 - Жиров Н.А. Сельская школа в повседневной жизни крестьянства аграрного центра России во второй половине XIX - начале XX вв. // Вопросы истории. 2020. № 11. С. 99-108. DOI: 10.31166/VoprosyIstorii202011Statyi39

Зайцева, 2010 - Зайцева Н.Е. Становление внешкольного образования в России в XIX - начале ХХ вв. // Проблемы и перспективы развития образования в России. 2010. № 6. С. 37-42.

Ивако, 2002 - Ивако Н.В. Уездное земство и развитие начального образования в российской провинции во второй половине XIX - начале XX в. (на примере Орловской губернии) // Вопросы гуманитарных наук. 2002. № 2. С. 10-12.

История..., 1897 - История начальной школы в Орловской губернии. Очерки деятельности уездных земств по народному образованию. Орел, 1897.

Клевцова, Жиров, 2019 - Клевцова О.В., Жиров Н.A. Сельский социум и образование во второй половине XIX - начале XX вв. (по материалам Елецкого уезда Орловской губернии) // История: факты и символы. 2019. № 4 (21). С. 119-126. DOI: 10.24888/2410-4205-2019-21-4-18-119-126

Козлов, 2012 - Козлов К.В. К истории православного внешкольного образования в России во второй половине XIX - начале XX вв.: церковные воскресные школы // Научные ведомости Белгородского государственного университета. 2012. Т. 23. № 13. С. 134-140.

Котомина, 2016 - Котомина А.А. Археология интермедиальности: публичные народные чтения с «волшебным фонарем» в России в 1872-1915 гг. // Практики и интерпретации. 2016. № 1 (4). C. $16-35$.

Кузовлев и др., 2006 - Кузовлев В.П., Перцев В.В., Саввина О.А. Развитие гимназического образования в Орловской губернии: Монография. Елец: ЕГУ им. И.А. Бунина, 2006. 235 с.

Маркарьян, 2013 - Маркарьян Т.В. Развитие внешкольного образования в Российской империи конца XIX - начала XX вв. // Вестник Сургутского государственного педагогического университета. 2013. № 6 (27). С. 167-172.

Обзор..., 1899 - Орловской губернии за 1898 год. Издание Орловского Губернского Статистического Комитета. Орел: Типография Губернского Правления, 77 с. № 14 .

ОЕВ, 1899 - Орловские епархиальные ведомости. Орел: Типография губернского правления, № 32 .

ОЕВ, 1909 - Орловские епархиальные ведомости. Орел: Типография губернского правления,

Першина, 2016 - Першина Ю.В. Народные чтения в Вятской губернии в начале XX в. как средство внешкольного просвещения населения // Научно-методический электронный журнал «Концепт». 2016. № 10. С. 191-199. [Электронный pecypc]. URL: http://e-koncept.ru/2016/16230.htm

Сборник справок..., 1899 - Сборник для справок в служебной практике причта: «календарь священника». Самара: Типография Духовной консистории, 1899. 410 с.

Стояновская, Стояновская, 2016 - Стояновская И.Б., Стояновская М.А. Общественнопедагогическое движение в российской провинции второй половины XIX - начала XX вв. (на материалах г. Ельца и его уезда) // История: факты и символы. 2016. № 1 (6). С. 38-48.

Филоненко, 2004 - Филоненко T.B. Развитие школьного образования в России в начале XX века // Вопросы истории. 2004. № 9. С. 137-142.

Хабалева, 2015 - Хабалева E.H. Особенности организации начального образования в Российской империи во второй половине XIX - начале XX века (на примере Орловской губернии) // Научный диалог. 2015. Выпуск № 8 (44). С. 97-114.

Eklof, 1990 - Eklof B. Russian Peasant Schools: Officialdom, Village Culture and Peasant Pedagogy 1861-1914, Berkeley: University of California Press, 1990, 652 p.

Klevcova, Zhirov, 2020 - Klevcova O.V. Zhirov N.A. Training Teaching Staff for National Schools in Russian Empire in the second half of the XIX century // Bylye Gody. 2020. 58(4): 2580-2587. DOI: $10.13187 / \mathrm{bg} .2020 .4 .2580$

\section{References}

Barynkina, Barynkin, 2015 - Barynkina, I.V., Barynkin, V.P. (2015). Rasprostranenie nachal'nogo obrazovaniya i prosveshcheniya na sele v Tsentral'noi Rossii v kontse XIX - nachale XX vv. (po materialam Kaluzhskoi, Orlovskoi i Smolenskoi gubernii) Distribution of primary education and education in the village 
in the Central Russia at the end of XIX - the beginning of the 2oth centuries (on materials of the Kaluga, Oryol and Smolensk province)]. Vestnik Bryanskogo gosudarstvennogo universiteta. 1: 22-24. [in Russian]

Belosludtseva, 2009 - Belosludtseva, V.V. (2009). Tserkovno-prikhodskaya shkola v sisteme nachal'nogo obrazovaniya $\mathrm{v}$ Rossii vo vtoroi polovine XIX v. [Parish school in system of primary education in Russia in the second half of the 19th century]. Vestnik Permskogo universiteta. 4(11): 95-96. [in Russian]

Buganov, 2008 - Buganov, A.V. (2008). O gramotnosti i chtenii russkikh krest'yan XIX - nachala XX vekov [About literacy and reading of Russian peasants of the XIX - early XX centuries]. Prepodavatel' XXI veka. 2: 50-57. [in Russian]

Eklof, 1990 - Eklof, B. (1990). Russian Peasant Schools: Officialdom, Village Culture and Peasant Pedagogy 1861-1914, Berkeley: University of California Press, 652 p.

Filonenko, 2004 - Filonenko, T.V. (2004). Razvitie shkol'nogo obrazovaniya v Rossii v nachale $\mathrm{XX}$ veka [The development of school education in Russia in the early twentieth century]. Voprosy istorii. 9: 137-142. [in Russian]

GAOO - Gosudarstvennyi arkhiv Orlovskoi oblasti (GAOO) [The Russian state historical archive].

Istoriya..., 1897 - Istoriya nachal'noi shkoly v Orlovskoi gubernii. Ocherki deyatel'nosti uezdnykh zemstv po narodnomu obrazovaniyu [History of elementary school in the Oryol province. Sketches of activities of district zemstvoes for national education]. Orel, 1897. [in Russian]

Ivako, 2002 - Ivako, N.V. (2002). Uezdnoe zemstvo i razvitie nachal'nogo obrazovaniya v rossiiskoi provintsii vo vtoroi polovine XIX - nachale XX v. (na primere Orlovskoi gubernii) [The county district council and the development of primary education in the Russian province in threesome half XIX - early XX century. (On an example of the Oryol province)]. Voprosy gumanitarnykh nauk. 2. S. 10-12. [in Russian] Khabaleva, 2015 - Khabaleva, E.N. (2015). Osobennosti organizatsii nachal'nogo obrazovaniya v Rossiiskoi imperii vo vtoroi polovine XIX - nachale XX veka (na primere Orlovskoi gubernii) Features of the organization of primary education in the Russian Empire in the second half of XIX - the beginning of the 20th century (on the example of the Oryol province)]. Nauchnyi dialog. 8(44): 97-114. [in Russian]

Klevcova, Zhirov, 2020 - Klevcova, O.V. Zhirov, N.A. (2020). Training Teaching Staff for National Schools in Russian Empire in the second half of the XIX century. Bylye Gody. 58(4): 2580-2587. DOI: $10.13187 /$ bg.2020.4.2580

Klevtsova, Zhirov, 2019 - Klevtsova, O.V., Zhirov, N.A. (2019). Sel'skii sotsium i obrazovanie vo vtoroi polovine XIX - nachale XX vv. (po materialam Eletskogo uezda Orlovskoi gubernii) [Rural society and education in the second half of the XIX - early XX centuries. (based on the materials of the Yelets district of the Oryol province]. Istoriya: fakty i simvoly. 4(21): 119-126. DOI: 10.24888/2410-4205-2019-21-4-18-119126. [in Russian]

Kotomina, 2016 - Kotomina, A.A. (2016). Arkheologiya intermedial'nosti: publichnye narodnye chteniya s «volshebnym fonarem» v Rossii v 1872-1915 gg. [Archeology of Intermediality: Public Folk Readings with a "magic lantern" in Russia in 1872-1915]. Praktiki i interpretatsii. 1(4): 16-35. [in Russian]

Kozlov, 2012 - Kozlov, K.V. (2012). K istorii pravoslavnogo vneshkol'nogo obrazovaniya v Rossii vo vtoroi polovine XIX - nachale XX vv.: tserkovnye voskresnye shkoly [On the History of Orthodox Extracurricular Education in Russia in the Second Half of the XIX - early XX centuries: Church Sunday Schools]. Nauchnye vedomosti Belgorodskogo gosudarstvennogo universiteta. T. 23. 13: 134-140. [in Russian]

Kuzovlev i dr., 2006 - Kuzovlev, V.P., Pertsev, V.V., Savvina, O.A. (2006). Razvitie gimnazicheskogo obrazovaniya v Orlovskoi gubernii: Monografiya [The development of gymnasium education in the Orel province: monograph]. Elets: EGU im. I.A. Bunina, 235 p. [in Russian]

Markar'yan, 2013 - Markar'yan, T.V. (2013). Razvitie vneshkol'nogo obrazovaniya v Rossiiskoi imperii kontsa XIX - nachala XX vv. [The development of extracurricular education in the Russian Empire of the late XIX - early XX centuries]. Vestnik Surgutskogo gosudarstvennogo pedagogicheskogo universiteta. 6(27): 167-172. [in Russian]

Obzor..., 1899 - Obzor Orlovskoi gubernii za 1898 god. Izdanie Orlovskogo Gubernskogo Statisticheskogo Komiteta [The review of the Oryol province for 1892. Edition of the Oryol Provincial Statistical Committee]. Orel: Tipografiya Gubernskogo Pravleniya, 77 p. [in Russian]

[in Russian]

OEV, 1899 - Orlovskie eparkhial'nye vedomosti. Orel: Tipografiya gubernskogo pravleniya, № 14 . [in Russian]

OEV, 1909 - Orlovskie eparkhial'nye vedomosti. Orel: Tipografiya gubernskogo pravleniya, № 32 .

Pershina, 2016 - Pershina, Yu.V. (2016). Narodnye chteniya v Vyatskoi gubernii v nachale XX v. kak sredstvo vneshkol'nogo prosveshcheniya naseleniya [Folk readings in the Vyatka province at the beginning of the XXth century as a means of extracurricular education of the population]. Nauchno-metodicheskii elektronnyi zhurnal «Kontsept». 10: 191-199. [Electronic resource]. URL: http://e-koncept.ru/2016/ 16230.htm [in Russian]

Sbornik spravok..., 1899 - Sbornik dlya spravok v sluzhebnoi praktike prichta: «kalendar' svyashchennika» [Collection for references in the official practice of the clergy: "the calendar of the priest"]. Samara: Tipografiya Dukhovnoi konsistorii, 1899.410 p. [in Russian] 
Stoyanovskaya, Stoyanovskaya, 2016 - Stoyanovskaya, I.B., Stoyanovskaya, M.A. (2016). Obshchestvenno-pedagogicheskoe dvizhenie v rossiiskoi provintsii vtoroi poloviny XIX - nachala KhKh vv. (na materialakh g. El'tsa i ego uezda) [The public and pedagogical movement in the Russian province of the second half of the XIX beginning of the 2oth centuries (on materials of Yelets and its county)]. Istoriya: fakty $i$ simvoly. 1(6): 38-48. [in Russian]

Vakhterova, 1897 - Vakhterova, V. (1897). Narodnye chteniya [Folk readings]. SPb.: «Russkaya shkola», 209 p. [in Russian]

Zaitseva, 2010 - Zaitseva, N.E. (2010). Stanovlenie vneshkol'nogo obrazovaniya v Rossii v XIX nachale XX vv. [The formation of extracurricular education in Russia in the XIX-early XX centuries]. Problemy i perspektivy razvitiya obrazovaniya $v$ Rossii. 6: 37-42. [in Russian]

Zhirov, 2020 - Zhirov, N.A. (2020). Sel'skaya shkola v povsednevnoi zhizni krest'yanstva agrarnogo tsentra Rossii vo vtoroi polovine XIX - nachale XX vv. [Rural school in the daily life of the peasantry of the agrarian center of Russia in the second half of the XIX - early XX centuries]. Voprosy istorii. 11: 99-108. DOI: 10.31166/VoprosyIstorii202011Statyi39 [in Russian]

\title{
Народные чтения как одна из форм организации сельского внешкольного образования в Орловской губернии во второй половине XIX - начале XX вв.
}

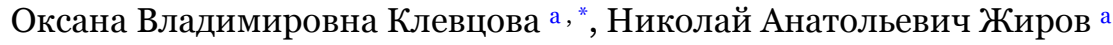 \\ а Елецкий государственный университет им. И.А. Бунина, Российская Федерация
}

Аннотация. Статья посвящена анализу ситуации в области распространения грамотности среди сельского, преимущественно крестьянского населения, посредством проведения народных чтений. Авторами предпринята попытка изучить законодательную базу, исследовать государственную политику и рекомендации по методике организации массовых народных чтений. Актуальность исследования состоит в слабой изученности внешкольной формы получения образования в Российской империи, в том числе в рамках Орловской губернии, в исследуемый период.

Особое внимание было уделено проведению чтений на территории Орловской губернии, анализу востребованности данного направления работы среди крестьянского населения.

В ходе исследования были использованы общенаучные методы анализа и синтеза, а также принцип историзма, сравнительно-исторический, математический и другие методы.

В результате исследования были установлены причины популярности народных чтений у жителей села. При этом было замечено отсутствие системности в проведении данной работы, плана организации и распространения религиозно-нравственного воспитания молодежи. Выявлены причины, тормозящие данный процесс: дефицит средств, скудная материальная и техническая база библиотек, отсутствие квалифицированных педагогов земских школ. Государство переложило ответственность на местную власть и общественность. При этом на протяжении всего исследуемого периода наблюдался устойчивый рост интереса среди крестьянского населения к народным чтениям и книгам.

Ключевые слова: религиозно-нравственные чтения, народная библиотека, внешкольное образование, крестьянство, земство, Орловская губерния.

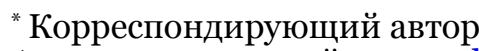

Адреса электронной почты: ksenijmel@yandex.ru (О.В. Клевцова), zhirov-nikolai@mail.ru (H.А. Жиров) 